\title{
Effect of the farm operations for wheat cultivation in fish ponds on the growth performance and total yield of Nile tilapia (Oreochromis niloticus).
}

\author{
Ahmed F. El-Bab ${ }^{1}$; Mohamed A. Mostafa ${ }^{1}$; Mohamed T. Shehab El-Din, M. $^{2}$ \\ and Amal S. Hassan ${ }^{1}$ \\ 1- Central Laboratory for Aquaculture Research, Agriculture Research Center. Fish \\ production Department. \\ 2- Central Laboratory for Aquaculture Research, Sakha Aquaculture Research Unit. Fish \\ diseases Department.
}

\section{ABSTRACT}

This study aimed to investigate the effect of farming operations for wheat production in fish ponds on growth and vitality for Oreochromis niloticus. Six earthen ponds $\left(4200 \mathrm{~m}^{2}\right)$ were used in this study. Fish farming showed two successive seasons followed by cultivating of wheat in the winter period. Fish farming of O. niloticus in the first season began on $17 / 5 / 2012$ up to $18 / 10 / 2012$ then cultivated by wheat on $8 / 11 / 2012$ up to $8 / 05 / 2013$ and thereafter stocked by $O$. niloticus on $25 / 5 / 2013$ up to $25 / 10 / 2013$. O. niloticus fish were fed on a diet containing $25 \%$ crude protein. Wheat culture was exposed to three treatments (two replicates for each treatment). The first treatment (T1) wheat was cultured without any fertilizers, while in the second treatment (T2) wheat was cultured with inorganic fertilization and in the third treatment (T3) wheat was cultured with organic fertilization. O. niloticus fingerlings averaging $30.20 \mathrm{~g}$ in weight in first year and $30.63 \mathrm{~g}$ for the second year at stocking rate (12000 fingerlings/feddan). Results obtained can be summarized as following:

Season of aquaculture: the second season recorded the highest averages of body weight (BW), body length (BL), condition factor (K), daily weight gain (DWG) and specific growth rate (SGR).

Treatments: The third treatment (T3) O. niloticus recorded the highest ranges of body weight $(\mathrm{BW})$, body length $(\mathrm{BL})$, condition factor $(\mathrm{K})$, daily weight gain (DWG) and specific growth rate (SGR).

Wheat culture: second treatment (T2) recorded the highest ranges of total weight of Wheat crop.

Based on the results obtained in this study and from the economical evaluation, it could be concluded that, Wheat cultivation in ponds during the winter period taking into account organic and inorganic fertilization for wheat crop, feeding $O$. niloticus on artificial feed containing $25 \%$ crude protein increased the weights of fish, as well as increased the yield of wheat production from fish ponds in addition to that it was best in terms of economic efficiency compared to other treatments.

Keywords: Fish ponds, cultivation of wheat, growth performance, Nile tilapia, O. niloticus.

\section{INTRODUCTION}

The Integrated Farming System (IFS) has revolutionized conventional farming of livestock, aquaculture, horticulture, agriculture, agro-industry and allied activities in some countries especially in tropical and subtropical regions that are arid. Farming all over the world is not very performing unless relatively big inputs are added to sustain yields and very often compromise the economic viability as well as the ecological sustainability. IFS can remove all the farming constraints including shortage and high cost of inputs and environmental pollution. This could be done by 
not only solving most of the existing economic and environmental problems, but also provides the needed means of production such as fuels, fertilizers and feed, besides increasing productivity many folds (Chan, 2006).

The benefits of integrated farming system are enormous and encompass those of traditional farming system (Ugwumba and Orji, 2006) and modern farming system (Igbinnosa, 2006). As described by Tokrishna (2006), integrated farming system reduces costs of production and thus increases farmer's productivity, income, nutrition and welfare. If properly adopted with investment in agriculture integrated farming system improves the financial return of farmers. Othman (2006) summarized the multifaceted benefits of integrated farming system to include economics benefits in terms of increased food production, social function in terms of provision of employment opportunities for excess labour force displaced from other sectors in the urban areas. Integrated farming system can be a complete integration system involving crops, livestock, fisheries, biogas, agro-industry and allied activities (Chan, 2006) or partial integration made up of different combinations of the later units (Thy, 2006; Igbinnosa and Okporie, 2013).

During 1980s and early 1990s, crops-fish culture as managed cultivation systems experienced a revival, as concerns over the widespread use of pesticides emerged. In several south East Asian countries, crops fields as natural fisheries are more important than as places where cultured fish are raised. Native fish species are favored over species which are generally cultured like the common carp, Nile tilapia and silver barb Chan, (2006) and Ebe, (2012). The present study aimed to study the effect of wheat cultivation in fish pond on productive performance of Nile tilapia.

\section{MATERIALS AND METHODS}

The study had been done in a private farm at Tollumbat No. 7 in Riyad City, Kafr El-Sheikh governorate, Delta district at the Northern part of Egypt to evaluate the Effect of farming operations for wheat production in fish ponds on the growth and vitality of $O$. niloticus. The pond preparation, for alternative culture, stocking density and pond daily management are described in details. Also, water quality measurements, fish sampling and data collection during harvest are recorded too. Equations and statistical methods for analysing the specific growth rate, daily weight gain and the condition factor are carried out according to SAS (1996).

\section{Experimental design:}

The current experiment was conducted using randomized block design for three treatments of similar surface area $\left(4200 \mathrm{~m}^{2}\right)$ in each pond. The experimental ponds were equal in water volume $\left(5040 \mathrm{~m}^{3}\right)$ and dimensions $(42 \times 100 \mathrm{~m})$ with the same average water depth of $120 \mathrm{~cm}$. The experimental ponds were stocked with $O$. niloticus (12000 fingerlings/feddan). The fingerlings were stocked at first season at an average initial total length of $14.77 \mathrm{~cm}$ and an average initial total weight of $30.20 \mathrm{~g}$ for all treatments. The average of initial total length at second season was $15.03 \mathrm{~cm}$ and an average initial total weight of $30.63 \mathrm{~g}$.

\section{Treatments:}

O. niloticus fish in all treatments were fed only on artificial feed containing $25 \%$ crude protein. The wheat cultured was exposed to three treatments (Two replicates for each treatment for fish and wheat culture). The first treatment wheat was cultured without any fertilizer, in the second treatment wheat was supplied by inorganic fertilization and in the third treatment wheat was supplied by with organic fertilization. 


\section{Pond management:}

The first season of this study was carried out during the period from 17/5/2012 (beginning the culture of $O$. niloticus) to $18 / 10 / 2012$ (154 days harvesting time) followed by cultivating wheat during the period from 8/11/2012 to $8 / 5 / 2012$ (160 days) and the second season began at 25/5/2012 and harvested at 25/10/2013 (154 days). In which the following culture practices were done.

\section{Supplementary feed for Oreochromis niloticus:}

Commercial diet was manufactured by local animal feed factory. Sample of fish feed was collected from several sacks and send for proximate chemical analysis at the Central Laboratory for Aquaculture Research at Abbassa. The fingerlings of the two seasons were fed commercial floating diet containing $25 \%$ crude protein (pellets $3 \mathrm{~mm}$ in diameter), and fish were fed six days per week at a daily feeding rate of $3 \%$ of the estimated fish-weight twice at $9.00 \mathrm{am}$ and $3.00 \mathrm{pm}$ during the experimental period. Feed was applied by broadcasting over pond water surface in the same place and fish were considered satiated when they did not show an interest on the feed.

Feed quantity was adjusted according to the average body weight of the sample in each pond. In order to determine the average weight of fish, biweekly samples were taken by seining where 30 fish / pond (replicate) were collected and then released again in the pond after individual measuring the weight and length.

\section{Water management:}

Water temperature, dissolved oxygen and $\mathrm{pH}$ were measured daily at 6 a.m. and 12 p.m. (during the two seasons of study) using thermometer, dissolved oxygen meter (YSI model 57) and pH meter (model Corning 345), respectively. Determinations of the other water quality parameters (alkalinity and ammonia) were carried out every two weeks according to the methods of Boyd (1979).

\section{Harvesting:}

At the end of the first season of this experiment $\left(18^{\text {td }}\right.$ of October, 2012) and $\left(25^{\text {td }}\right.$ of October, 2013) for second season, ponds were gradually drained from the water and fish were harvested and transferred to fiberglass tanks and carried to the processing center where they washed, and the fish were sorted and collectively weighed.

\section{Wheat culture:}

After the end of fish culture and harvesting of fish, wheat seeds were planted at the third week of November, after conducting different service to the wheat crop from the plow and the settlement of the pelvic floor.

The seeds were flooded in water for 24 hours followed by air drying and distributed using stores tractors on fish pond wet. The seeds were distributed in the field at suitable depth and a suitable quantity of seeds. Used $60 \mathrm{Kg}$ of wheat seed for germination and $10 \mathrm{~kg}$ of wheat seeds for patching as recommended by Baotong (1984) and Salah, (2003).

\section{Fertilizers applications for wheat:}

Considered fertilizers, especially nitrogen fertilizers are of important factors that lead to an increase in crop condition that fertilizers were added in quantities specified in appointments recommended (Jian et al., 2011).

Ponds were fertilized at the $22^{\text {nd }}$ weeks. Fertilization occurred once a week by broadcasting of:

-Organic fertilizer: Adding organic fertilizers (cattle manure) led to improvement of the properties of the natural soil the organic fertilization was added to the soil at a rate of $16 \mathrm{~m}^{3} /$ Feddan, provided that the compost old and Degradable. 


\section{-Inorganic fertilizers:}

Phosphate fertilization: superphosphate was added phosphate $15 \% \quad \mathrm{P}_{2} \mathrm{O}_{5}$ (triphosphate) at a rate of $100 \mathrm{~kg}$ fertilizer/feddan and prose on the field, soil was plowed and permuted during the second plowing after soil settlement.

Nitrogen fertilization: In addition to phosphate, ammonium nitrate fertilizer was added at a rate of $100 \mathrm{~kg} /$ feddan

\section{Irrigation:}

The irrigation of ponds was four times only because of the remainder of the water in ponds. And taken into account accuracy in planting dates because increasing of irrigation times cause swelling of seeds. Also decreasing irrigation times cause less germination rate. And the Irrigation was after about 50 days of agriculture and then every 25 days and prevent irrigation when it is characterized by the arrival of plants to physiological maturity stage.

\section{Fish samples and measurements:}

Random samples (30 fish of $O$. niloticus from each pond) were taken randomly biweekly during the experimental period. During this experiment, body measurements (body weight in $\mathrm{g}$ and body length in $\mathrm{cm}$ ) were recorded 8 times, at biweekly interval throughout the whole experiment period.

Condition factor was determined by using the following formula:

$\mathbf{K} \%=\left[\right.$ weight $(\mathrm{g}) /$ length $\left.(\mathrm{cm})^{3}\right] \times 100$

Specific growth rate was calculated according to Jauncey and Rose (1982) by using the following formula:

$$
\mathbf{S G R} \%=\frac{\mathrm{LnW} 2-\mathrm{LnW} 1}{\mathrm{t}} \times 100
$$

\section{Hematogram and Chemical analysis of serum:}

At the end of the fattening period, blood samples were taken from the caudal vein of fish by sterile syringe using EDTA solution used as an anticoagulant. The blood samples were used for determining of erythrocyte and leukocyte count (Dacie and Lewis, 1984), hemoglobin content (Vankampen, 1961) and packed cell volume (PCV) was calculated according to the formula mentioned by Britton (1963).

Serum was obtained by centrifugation of blood at $3000 \mathrm{rpm}$ for $15 \mathrm{~min}$ and nonhaemolyzed serum was stored in deep freezer for further biochemical analyses. Total protein content was determined calorimetrically according to Henry (1964). Serum albumin was estimated by a colorimetric method according to Dumas and Biggs (1972) using commercial kit. Globulin content was calculated by mathematical subtraction of albumin value from that of the total protein. Activities of Aspartate Amino tansferase (AST), Alanine Aminotransferase (ALT), urea and creatinin were determined calorimetrically according to Reitman and Frankel, (1957).

\section{Statistical analysis:}

The statistical analysis of data collected was carried out by applying the computer program (SAS, 1996) by adopting the following fixed model:

$\mathrm{xij}=\mu . .+\alpha \mathrm{i}+\beta \mathrm{j}+\alpha \beta \mathrm{ij}$.

Where:

Xij = observation of the ijkl-th fish $\quad \mu=$ Overall mean. $\alpha i=$ the effect of $I-$ th year.

$\beta \mathrm{j}=$ the effect of $\mathrm{J}$-th tratment.

$\alpha \beta \mathrm{ij}=$ the effect of interaction between I-th year and treatment J-th.

Differences among means were tested for significance according to Duncan's multiple range tests (Duncan, 1955). 


\section{RESULTS AND DISCUSSION}

\section{Water Quality parameters:}

Results of water quality parameters of the experimental ponds during the experimental period (2012 and 2013) as averages of the monthly samples are summarized in Table (1). In general, averages of water temperature readings during the two periods ranged from $25.8,25.4$ and $25.7^{\circ} \mathrm{C}$ for year 2012 and $26.5,26.9$ and $27.5{ }^{\circ} \mathrm{C}$ for year 2013. Dissolved oxygen ranged between 5.2, 5.4 and $5.4 \mathrm{mg} / 1$ and 5.1, 4.6 and 4.1mg / 1. for two years 2012 and 2013, respectively. Avila et al. (2012) reported that $2.3 \mathrm{mg} \mathrm{DO} / 1$ is above the normal tolerance level of tilapia.

Table 1: Some water quality parameters of earthen ponds during to two periods.

\begin{tabular}{|c|c|c|c|c|c|c|c|}
\hline Variable & \multirow{2}{*}{ NO. } & \multicolumn{7}{|c|}{$\mathbf{2 0 1 2}$} & \multicolumn{2}{c|}{$\mathbf{2 0 1 3}$} \\
\cline { 3 - 8 } & & $\mathbf{T 1}$ & $\mathbf{T 2}$ & $\mathbf{T 3}$ & $\mathbf{T 1}$ & $\mathbf{T 2}$ & T3 \\
\hline Tem.(C) & 6 & $25.8 \pm 0.9$ & $25.4 \pm 0.9$ & $25.7 \pm 0.9$ & $26.5 \pm 0.9$ & $26.9 \pm 0.9$ & $27.5 \pm 0.9$ \\
\hline DO oxygen & 6 & $5.2 \pm 0.6$ & $5.4 \pm 0.6$ & $5.4 \pm 0.6$ & $5.1 \pm 0.6$ & $4.6 \pm 0.6$ & $4.1 \pm 0.6$ \\
\hline PH & 6 & $7.5 \pm 0.8$ & $7.2 \pm 0.8$ & $7.1 \pm 0.8$ & $7.6 \pm 0.8$ & $8.0 \pm 0.8$ & $8.3 \pm 0.8$ \\
\hline S. disk (cm) & 6 & $24.3 \pm 2.1$ & $25.2 \pm 2.1$ & $24.7 \pm 2.1$ & $25.4 \pm 2.1$ & $26.8 \pm 2.1$ & $27.1 \pm 2.1$ \\
\hline NH $_{\mathbf{3}} \mathbf{~ m g / l}$ & 6 & $0.033 \pm 0.003$ & $0.031 \pm 0.003$ & $0.033 \pm 0.003$ & $0.034 \pm 0.003$ & $0.037 \pm 0.003$ & $0.039 \pm 0.003$ \\
\hline $\mathbf{N O}_{\mathbf{2}} \mathbf{~ m g / l}$ & 6 & $0.036 \pm 0.004$ & $0.37 \pm 0.004$ & $0.35 \pm 0.004$ & $0.35 \pm 0.004$ & $0.042 \pm 0.004$ & $0.041 \pm 0.004$ \\
\hline $\mathbf{N O}_{\mathbf{3}} \mathbf{~ m g / l}$ & 6 & $0.10 \pm 0.03$ & $0.10 \pm 0.03$ & $0.11 \pm 0.03$ & $0.11 \pm 0.03$ & $0.12 \pm 0.03$ & $0.12 \pm 0.03$ \\
\hline T. alk. (mg/l) & 6 & $395.7 \pm 6.7$ & $406.5 \pm 6.7$ & $411.2 \pm 6.7$ & $414.9 \pm 6.7$ & $426.4 \pm 6.7$ & $431.0 \pm 6.7$ \\
\hline
\end{tabular}

pH ranged between 7.5, 7.2 and 7.1 for year 2012 and 7.6. 8.0 and 8.3 for year 2013. White and Reddy (2003) reported that waters with a $\mathrm{pH}$ range of $6.5-9$ are the most suitable for fish production. The average value of seechi disk readings were $24.3,25.2$ and $24.7 \mathrm{~cm}$ for year 2012 and $25.4,26.8$ and $27.1 \mathrm{~cm}$ for years 2013 , respectively. The significant increase in seechi disk reading higher than $20 \mathrm{~cm}$ for all treatments of year 2013 indicates that pond is too turbid, which may be due to the presence of either phytoplankton or suspended soil particles (Boyd 1998). The average concentration of unionized ammonia $\left(\mathrm{NH}_{3}\right)$ was $0.033,0.031$ and $0.039 \mathrm{mg} / 1$ for year 2012 and $0.034,0.037$ and $0.039 \mathrm{mg} / 1$ for year 2013. Increasing concentrations of ammonia in year 2013 may return to the fertilization of organic and inorganic during the wheat culture. Ayas et al. (2013) reported that, ammonia concentration of $0.374-0.410 \mathrm{mg} / 1$ was recorded in ponds fertilized with both chicken manure and inorganic fertilizers in combination.

The values of the total alkalinity ranged between $395.7,406.5$ and 411.2 for year 2012 and 414.9, 426.4 and $431.0 \mathrm{mg} / \mathrm{l}$, for years 2013 . The above results showed that all parameters of water quality were in the suitable range for culture of Nile tilapia, (Gikas and Tsihrintzis 2012).

Wheat yield:

Data in Table (2) recorded the effect of artificial feed for feeding fish, organic and in organic fertilization for fish ponds on wheat yield and its components. The data indicated that all characters were significantly affected by organic and in organic fertilization. 
Table 2: effect of organic and in organic fertilization for fish ponds on wheat yield and its parameters.

\begin{tabular}{|c|c|c|c|c|}
\hline parameter & No. & T1 & $\mathbf{T 2}$ & T3 \\
\hline No. of tiller $/ \mathrm{m}^{2}$ & 3 & $304.23 \pm 7.6 \mathrm{c}$ & $349.07 \pm 7.6 \mathrm{a}$ & $338.89 \pm 7.6 b$ \\
\hline No. of spikes $/ \mathrm{m}^{2}$ & 3 & $291.12 \pm 4.4 b$ & $312.15 \pm 4.4 \mathrm{a}$ & $313.45 \pm 4.4 \mathrm{a}$ \\
\hline Spike length (cm) & 3 & $9.66 \pm 1.3 \mathrm{~b}$ & $12.60 \pm 1.3 \mathrm{a}$ & $11.80 \pm 1.3 \mathrm{a}$ \\
\hline 100 grain weight & 3 & $4.29 \pm 0.6 \mathrm{c}$ & $4.97 \pm 0.6 \mathrm{a}$ & $4.85 \pm 0.6 \mathrm{~b}$ \\
\hline No. of grains/spike & 3 & $50.39 \pm 2.1 \mathrm{~b}$ & $65.18 \pm 2.1 \mathrm{a}$ & $63.96 \pm 2.1 \mathrm{a}$ \\
\hline No. of grains $/ \mathrm{m}^{2}$ & 3 & $14669.50 \pm 38.55 \mathrm{c}$ & $20345.90 \pm 38.55 a$ & $20048.30 \pm 38.55 b$ \\
\hline weight of grains $(\mathrm{g}) / \mathrm{m}^{2}$ & 3 & $629.32 \pm 22.14 \mathrm{ca}$ & $1011.19 \pm 22.14 \mathrm{a}$ & $972.34 \pm 22.14 b$ \\
\hline grains yield kg/feddan & 3 & $2643.16 \pm 28.72 \mathrm{c}$ & $4247.01 \pm 28.72 \mathrm{a}$ & $4083.83 \pm 28.72 b$ \\
\hline straw yield kg/feddan & 3 & $2733 \pm 27.91 \mathrm{c}$ & $2845 \pm 27.91 \mathrm{a}$ & $2808 \pm 27.91 b$ \\
\hline
\end{tabular}

$\mathrm{a}, \mathrm{b}, \mathrm{c} \pm$ records of the same row having the same letter do not differ significantly $(\mathrm{P}<0.05)$ other wise they do.

The highest values of studied characters parameters i.e. number of tiller $/ \mathrm{m}^{2}$, number of spikes $/ \mathrm{m}^{2}$, number of grains/spike, 100 grain weight $(\mathrm{g})$, straw yields $(\mathrm{Kg} / \mathrm{fed})$ and grain yield( $\mathrm{kg} / \mathrm{fed})$, were obtained by organic and inorganic fertilization for fish ponds compared to the control group. Furthermore T2 recorded the highest $(\mathrm{P}<0.05)$ values followed in a decreasing significant order by $\mathrm{T} 3$ and $\mathrm{T} 1$, respectively except No. of spikes $/ \mathrm{m}^{2}$, spike length $(\mathrm{cm})$ and 100 grain weight where T3 and T2 were significantly higher in this traits than the control group.

In this respect, Jürg and Donald (2013) reported that, when a fertilizer containing phosphorus is applied, only 10 percent to 30 percent (broadcast compared to seed-applied) is absorbed by the wheat. The remaining 70 percent to 90 percent of the applied phosphorus remains in the soil as residual phosphorus. However, less than 25 percent of residual phosphorus is generally found in the following year's soil tests for phosphorus when the phosphorus is broadcasted and mixed with the soil. Studies have shown that residual phosphorus availability can increase significantly when it is knifed-in below tillage depth. Such bands may provide some soluble phosphorus for several years, but the primary effect occurs during the following year. Therefore, residual phosphorus from banding is most effective in continuous cropping systems and less effective in fallow and ecofallow systems because of the longer time between phosphorus application and seeding of the next crop (Jürg and Donald, 2013).

Applying banded phosphate to irrigation winter of wheat at the seeding is extremely important. Phosphate helps the plants to establish good root systems and crowns going into winter and helps winter survival. Broadcast phosphate may be better than no phosphate, but the difference in efficiency between the two applications in winter wheat is very pronounced. (Franzen, et al., 2008). Stephen (2007) found that, integrated aquaculture and crops provided the soil and water conservation and agricultural land and erosion control, by using the following formula:management of runoff water, soil, and improve the quality of soil and crop protection and nutrient and pest management, or otherwise causes soil degradation.

\section{Hematogram and Chemical analysis of serum:}

Changes in the physiological state often reflect the alteration of hematologic and blood biochemical values. Clinical chemical analysis is a fundamental tool used to diagnose and predict the outcome of diseases and to monitor the effects of therapeutic, nutritional and environmental management in human and veterinary medicine (Shalaby et al., 2006). 
Data presented in Table (3-a) indicated that there were significant improvement in the hematogram of fish in the year 2013 than that of year 2012. These results indicated that, culture of Nile tilapia after wheat culture increased fish health status. Such improvement may be attributed to that integration increases of the phytoplankton, zooplankton and other aquatic organisms that fish get them easily.

Table 3-a: Least-square means and tested standard error of hematogram at the end of this experiment.

\begin{tabular}{|c|c|c|c|c|c|}
\hline Variable & No. & RBCs Mill/Cmm & WBCs Mill/Cmm & hemoglobin G/DL & PCV\% \\
\hline Year (Y) & & & & & \\
\hline Y1 & 18 & $0.60 \pm 0.02 \mathrm{~b}$ & $56.47 \pm 3.05 \mathrm{~b}$ & $3.95 \pm 0.35 \mathrm{~b}$ & $27.83 \pm 2.24 \mathrm{a}$ \\
\hline Y2 & 18 & $0.74 \pm 0.02 \mathrm{a}$ & $62.00 \pm 3.05 \mathrm{a}$ & $5.31 \pm 0.35 \mathrm{a}$ & $27.00 \pm 2.24 \mathrm{a}$ \\
\hline Treatments (T) & & & & & \\
\hline T1 & 12 & $0.67 \pm 0.03 \mathrm{a}$ & $57.25 \pm 3.27 \mathrm{~b}$ & $4.70 \pm 0.42 \mathrm{a}$ & $27.65 \pm 2.43 \mathrm{a}$ \\
\hline T2 & 12 & $0.68 \pm 0.03 \mathrm{a}$ & $60.50 \pm 3.27 \mathrm{a}$ & $4.72 \pm 0.42 \mathrm{a}$ & $27.75 \pm 2.43 \mathrm{a}$ \\
\hline T3 & 12 & $0.68 \pm 0.03 \mathrm{a}$ & $59.95 \pm 3.27 \mathrm{ab}$ & $4.48 \pm 0.42 \mathrm{a}$ & $26.85 \pm 2.43 \mathrm{a}$ \\
\hline Interaction between Y*T & & & & & \\
\hline Y1*T1 & 6 & $0.62 \pm 0.04 \mathrm{~b}$ & $54.00 \pm 3.46 \mathrm{c}$ & $4.10 \pm 0.53 \mathrm{~b}$ & $28.10 \pm 2.43 \mathrm{a}$ \\
\hline Y1*T2 & 6 & $0.59 \pm 0.04 \mathrm{~b}$ & $57.50 \pm 3.46 \mathrm{~b}$ & $3.95 \pm 0.53 \mathrm{c}$ & $28.50 \pm 2.43 \mathrm{a}$ \\
\hline Y1*T3 & 6 & $0.60 \pm 0.04 \mathrm{~b}$ & $57.90 \pm 3.46 \mathrm{~b}$ & $3.80 \pm 0.53 \mathrm{c}$ & $26.90 \pm 2.43 \mathrm{c}$ \\
\hline Y2*T1 & 6 & $0.71 \pm 0.04 \mathrm{ab}$ & $60.50 \pm 3.46 \mathrm{ab}$ & $5.30 \pm 0.53 \mathrm{a}$ & $27.20 \pm 2.43 \mathrm{~b}$ \\
\hline Y2*T2 & 6 & $0.77 \pm 0.04 \mathrm{a}$ & $63.50 \pm 3.46 \mathrm{a}$ & $5.50 \pm 0.53 \mathrm{a}$ & $27.00 \pm 2.43 \mathrm{~b}$ \\
\hline Y2*T3 & 6 & $0.75 \pm 0.04 \mathrm{a}$ & $62.00 \pm 3.46 \mathrm{a}$ & $5.15 \pm 0.53 \mathrm{a}$ & $26.00 \pm 2.43 \mathrm{c}$ \\
\hline
\end{tabular}

$\mathrm{a}, \mathrm{b}, \mathrm{c} \pm$ Means with the same letter in each column are not significantly different $(\mathrm{P} \geq 0.05)$.

Moreover the data presented in Table (3-b) showed improvement concerning biochemical analysis too. As fertilization stimulates the development of bacteria in the water (probiotics) which not only accelerates the decomposition of organic matter, but also serve as food for the zooplankton, which form the nutritious and preferred food for many aquaculture species.

Table 3-b: Least-square means and tested standard error of biochemical analysis at the end of this experiment.

\begin{tabular}{|c|c|c|c|c|c|c|}
\hline Variable & No. & Total protein (g/dl) & Albumin g/dl & Globulin g/dl & AST U/L & ALT U/L \\
\hline Year (Y) & & & & & & \\
\hline Y1 & 18 & $3.05 \pm 0.04 \mathrm{a}$ & $1.43 \pm 0.04 \mathrm{a}$ & $1.82 \pm 0.06 \mathrm{~b}$ & $86.47 \pm 2.87 \mathrm{a}$ & $22.83 \pm 1.16 \mathrm{a}$ \\
\hline Y2 & 18 & $3.32 \pm 0.04 \mathrm{a}$ & $1.08 \pm 0.04 \mathrm{~b}$ & $2.33 \pm 0.06 \mathrm{a}$ & $71.63 \pm 2.87 \mathrm{~b}$ & $22.20 \pm 1.16 \mathrm{a}$ \\
\hline Treatments (T) & & & & & & \\
\hline T1 & 12 & $3.20 \pm 0.06 \mathrm{a}$ & $1.20 \pm 0.05 \mathrm{a}$ & $2.13 \pm 0.08 \mathrm{a}$ & $77.00 \pm 3.10 \mathrm{~b}$ & $23.00 \pm 1.33 \mathrm{a}$ \\
\hline T2 & 12 & $3.30 \pm 0.06 \mathrm{a}$ & $1.28 \pm 0.05 \mathrm{a}$ & $2.10 \pm 0.08 \mathrm{a}$ & $78.80 \pm 3.10 \mathrm{~b}$ & $21.80 \pm 1.33 \mathrm{a}$ \\
\hline T3 & 12 & $3.05 \pm 0.06 \mathrm{a}$ & $1.30 \pm 0.05 \mathrm{a}$ & $2.00 \pm 0.08 \mathrm{a}$ & $81.50 \pm 3.10 \mathrm{a}$ & $22.75 \pm 1.33 \mathrm{a}$ \\
\hline Interaction between $\mathbf{Y}^{*} \mathbf{T}$ & & & & & & \\
\hline Y*T1 & 6 & $3.05 \pm 0.07 \mathrm{~b}$ & $1.35 \pm 0.06 \mathrm{ab}$ & $1.96 \pm 0.10 \mathrm{~b}$ & $77.30 \pm 3.42 \mathrm{~b}$ & $23.20 \pm 1.67 \mathrm{a}$ \\
\hline Y1*T2 & 6 & $3.02 \pm 0.07 \mathrm{~b}$ & $1.55 \pm 0.06 \mathrm{a}$ & $1.80 \pm 0.10 \mathrm{bc}$ & $95.00 \pm 3.42 \mathrm{a}$ & $21.90 \pm 1.67 \mathrm{~b}$ \\
\hline Y1*T3 & 6 & $2.90 \pm 0.07 \mathrm{~b}$ & $1.40 \pm 0.06 \mathrm{a}$ & $1.70 \pm 0.10 \mathrm{c}$ & $76.00 \pm 3.42 \mathrm{~b}$ & $23.40 \pm 1.67 \mathrm{a}$ \\
\hline Y2*T1 & 6 & $3.35 \pm 0.07 \mathrm{a}$ & $1.05 \pm 0.06 \mathrm{c}$ & $2.30 \pm 0.10$ & $76.70 \pm 3.42 \mathrm{~b}$ & $22.80 \pm 1.67 \mathrm{ab}$ \\
\hline Y2*T2 & 6 & $3.40 \pm 0.07 \mathrm{a}$ & $1.00 \pm 0.06 \mathrm{c}$ & $2.40 \pm 0.10 \mathrm{aa}$ & $70.50 \pm 3.42 \mathrm{c}$ & $21.70 \pm 1.67 \mathrm{c}$ \\
\hline Y2*T3 & 6 & $3.20 \pm 0.07 \mathrm{a}$ & $1.20 \pm 0.06 \mathrm{~b}$ & $2.30 \pm 0.10 \mathrm{a}$ & $67.70 \pm 3.42 \mathrm{~d}$ & $22.10 \pm 1.67 \mathrm{ab}$ \\
\hline
\end{tabular}

$\mathrm{a}, \mathrm{b}, \mathrm{c} \pm$ Means with the same letter in each column are not significantly different $(\mathrm{P} \geq 0.05)$. 
Since fertilizer benefits the growth of bacteria and benthos, thus provides supplementary food for zooplankton and fish, thus improvs fish vitality, activating the liver cells, increasing the anabolic capacity to produce blood proteins particularly globulin. However, these remarks came more or less cloose to those mentioned by Baotong (1983) and Sophin (2007).

\section{Body weight:}

Table (4) shows means of body weights, at the start and end of this experiment as affected by years Y1 (2012) and Y2 (2013). As described in this table, the averages of initial weights of $O$. niloticus were 32.20 and $30.63 \mathrm{~g}$ respectively; while at the end of the experiment, the averages of body weight for Oreochromis niloticus were 313.07 and $322.33 \mathrm{~g}$, for two years $\mathrm{Y} 1$ and $\mathrm{Y} 2$, respectively regardless treatments applied. These results indicate that, the body weight for the second year was higher than that obtained in the first year. The differences between tow years were significant $(\mathrm{P}<0.05)$.

Regarding to the effect of pond treatments on body weight, Table (4) also showes that, the averages of initial body weight was $31.50,31.80$ and $31.10 \mathrm{~g}$ for three treatments T1, T2 and T3, respectively. While at the end of experiment the averages of body weight for treatments were $305.14,321.70$ and $326.25 \mathrm{~g}$ for the three treatments $\mathrm{T} 1, \mathrm{~T} 2$ and $\mathrm{T} 3$, respectively regardless of year. These results indicate that, the average body weight for wheat fertilization by inorganic fertilizer was higher $(\mathrm{P}<0.05)$ than other treatments. The analysis of variance of these results indicates that, the differences among treatments were significant $(\mathrm{P}<0.05)$. These results closely met the benefits summarized by Othman (2006).

Table 4: Least-square means and tested standard error of the factors affecting on body weight (gm) and body length $(\mathrm{cm})$.

\begin{tabular}{|c|c|c|c|c|c|}
\hline Variable & No. & Initial weight & Final weight & Initial length & Final length \\
\hline Year (Y) & & & & & \\
\hline Y1 & 360 & $32.20 \pm 0.91 \mathrm{a}$ & $313.07 \pm 3.60 \mathrm{~b}$ & $14.77 \pm 0.73 \mathrm{~b}$ & $31.93 \pm 1.27 \mathrm{a}$ \\
\hline Y2 & 360 & $30.63 \pm 0.91 \mathrm{a}$ & $322.33 \pm 3.60 \mathrm{a}$ & $15.03 \pm 0.73 \mathrm{a}$ & $31.63 \pm 1.27 \mathrm{a}$ \\
\hline Treatments (T) & & & & & \\
\hline T1 & 240 & $31.50 \pm 0.97 \mathrm{a}$ & $305.14 \pm 3.21 \mathrm{~b}$ & $15.20 \pm 0.90 \mathrm{a}$ & $32.07 \pm 1.09 \mathrm{a}$ \\
\hline T2 & 240 & $31.80 \pm 0.97 \mathrm{a}$ & $321.70 \pm 3.21 \mathrm{a}$ & $15.05 \pm 0.90 \mathrm{a}$ & $32.55 \pm 1.09 \mathrm{a}$ \\
\hline T3 & 240 & $31.10 \pm 0.97 \mathrm{a}$ & $326.25 \pm 3.21 \mathrm{a}$ & $15.70 \pm 0.90 \mathrm{a}$ & $30.80 \pm 1.09 \mathrm{~b}$ \\
\hline Interaction between Y*T & & & & & \\
\hline Y1*T1 & 120 & $31.96 \pm 0.78 \mathrm{a}$ & $311.52 \pm 2.37 \mathrm{~b}$ & $14.92 \pm 0.93 \mathrm{a}$ & $32.90 \pm 1.07 \mathrm{a}$ \\
\hline Y1*T2 & 120 & $32.29 \pm 0.78 \mathrm{a}$ & $310.22 \pm 2.37 \mathrm{~b}$ & $14.84 \pm 0.93 \mathrm{a}$ & $32.45 \pm 1.07 \mathrm{a}$ \\
\hline Y1*T3 & 120 & $32.58 \pm 0.78 \mathrm{a}$ & $314.57 \pm 2.37 \mathrm{~b}$ & $14.61 \pm 0.93 \mathrm{a}$ & $31.50 \pm 1.07 \mathrm{~b}$ \\
\hline Y2*T1 & 120 & $30.92 \pm 0.78 \mathrm{~b}$ & $298.78 \pm 2.37 \mathrm{c}$ & $15.07 \pm 0.93 \mathrm{a}$ & $31.10 \pm 1.07 \mathrm{~b}$ \\
\hline Y2*T2 & 120 & $30.65 \pm 0.78 \mathrm{~b}$ & $333.23 \pm 2.37 \mathrm{a}$ & $14.98 \pm 0.93 \mathrm{a}$ & $32.70 \pm 1.07 \mathrm{a}$ \\
\hline Y2*T3 & 120 & $30.47 \pm 0.78 \mathrm{~b}$ & $335.00 \pm 2.37 \mathrm{a}$ & $15.02 \pm 0.93 \mathrm{a}$ & $32.10 \pm 1.07 \mathrm{a}$ \\
\hline
\end{tabular}

$\mathrm{a}, \mathrm{b}, \mathrm{c} \pm$ Means with the same letter in each column are not significantly different $(\mathrm{P} \geq 0.05)$.

Inaddition, variations were significant $(\mathrm{P}<0.05)$ due to the interaction between years $\mathrm{Y} 1$ and $\mathrm{Y} 2$ and treatments $\mathrm{T} 1, \mathrm{~T} 2$ and $\mathrm{T} 3$ which indicated that these two factors act dependently on each other and also each of them had its own significant effect. The averages of initial body weight of $O$. niloticus were $31.96,32.29,32.58,30.92$, 30.65 and $30.47 \mathrm{~g}$; while at the end of the experiment, the averages of body weight were $311.52,310.22,314.57,298.78,333.23$ and $335.00 \mathrm{~g}$, respectively for the treatments $\mathrm{Y} 1{ }^{*} \mathrm{~T} 1, \mathrm{Y} 1 * \mathrm{~T} 2, \mathrm{Y} 1 * \mathrm{~T} 3, \mathrm{Y} 2 * \mathrm{~T} 1, \mathrm{Y} 2 * \mathrm{~T} 2$ and $\mathrm{Y} 1 * \mathrm{~T} 3$. As shown in Table (4), the best final weight was obtained for (Y2*T3, being 335.55g). This result may be due to adding organic or inorganic fertilization for crops to improve soil properties 
and increases the nitrogen, resulting in better utilization from nitrogen for Nile tilapia and increased of body weight. These results are in agreement with Stephen (2007) who found that, the fertilization of crops improved soil and water conservation and erosion control land and agriculture, water management and water runoff, also causes the increase of weight and vitality of fish cultured after crops farm.

As described by Tokrishna (2006), the Integrated Farming System reduces the cost of production and thus increases farmer's productivity, income, nutrition and welfares. If properly adopted with investment in agriculture IFS improves the personal savings and health of farmers.

Jian et al. (2011) found that, farmed fish with field crops has led to positive interactions and integrated use of resources between species generate appropriate ecosystem and all modern agricultural systems characteristics have been improved by exploiting synergies between species where alternative culture causes increasing the weights of both crops and fish, because the feces of fish reduced the fertilizers which used to produce crops and nitrogen found in soil reduced the fertilization which used for farmed fish and increased fish weights and total yield.

\section{Body length:}

Table (4) shows means of body length, at the begening and end of the experiment in years Y1 (2012) and Y2 (2013). As described in this table, the averages of initial body length of $O$. niloticus were 14.77 and $15.03 \mathrm{~cm}$ for $\mathrm{Y} 1$ and $\mathrm{Y} 2$, respectively regardless of treatments; while at the end of the experiment, the averages of body length for O. niloticus were 31.93 and $31.63 \mathrm{~cm}$ for $\mathrm{Y} 1$ and $\mathrm{Y} 2$, respectively. These results indicate that, the body length for the first year was higher than that obtained in second year. The differences between the two years were in significant.

Regarding to the effect of pond treatments on body length, Table (4) shows that, the averages of initial body length was $15.20,15.05$ and $15.70 \mathrm{~cm}$ for three treatments T1, T2 and T3, respectively. While at the end of the experiment, the averages of body length for treatments were $32.07,32.33$ and $30.80 \mathrm{~cm}$ for the three treatments T1, T2 and $\mathrm{T} 3$, respectively.

Results presented in Table (4) show that variations were significant $(\mathrm{P}<0.05)$ due to the interaction between years $\mathrm{Y} 1$ and $\mathrm{Y} 2$ and treatments $\mathrm{T} 1, \mathrm{~T} 2$ and $\mathrm{T} 3$ which indicated that these two factors act dependently on each other and also each of them had its own significant effect. The averages of initial body length of $O$. niloticus were $14.92,14.84,14.61,15.07,14.98$ and $15.02 \mathrm{~cm}$; while at the end of the experiment, the averages of body length were $32.90,32.45,31.50,31.10,32.70$ and $32.10 \mathrm{~cm}$, respectively for treatments $\mathrm{Y} 1 * \mathrm{~T} 1, \mathrm{Y} 1 * \mathrm{~T} 2, \mathrm{Y} 1 * \mathrm{~T} 3, \mathrm{Y} 2 * \mathrm{~T} 1, \mathrm{Y} 2 * \mathrm{~T} 2$ and $\mathrm{Y} 1 * \mathrm{~T} 3$. As shown in this Table, the best final body length was obtained for the second treatment (Y2*T2, being $32.70 \mathrm{~cm}$ ) at the second year. Osman (2006) summarized the Integrated Farming Systems to include the economic benefits in terms of increased food production, where the integrated farming system has led to an increase in tiller length of crops and increasing the length of Nile tilapia. Ugwumba and Orji (2006) reported that, the integrated farming system increased weight gain and length of Nile tilapia.

\section{Condition Factor (K):}

Table (5) shows means of Condition Factor (K), at the start and the end of the experiment as affected by years Y1 and Y2. As described in this table, the averages of initial $(\mathrm{K})$ of $O$. niloticus were 1.04 and 0.89 respectively; while at the end of the experiment, the means of $(\mathrm{K})$ for $O$. niloticus were 0.97 and 1.02 for $\mathrm{Y} 1$ and $\mathrm{Y} 2$, respectively. These results indicate that, the Condition Factor (K) for first year was higher than obtained in second year. 
Table 5: Least-square means and standard error of the tested factors affecting on condition factor (K), daily weight gain (DWG) and specific growth rate (SGR).

\begin{tabular}{|c|c|c|c|c|c|}
\hline Variable & No. & Initial K & Final K & $\begin{array}{c}\text { Daily weight gain (DWG), } \\
\text { G/fish }\end{array}$ & $\begin{array}{c}\text { Specific growth rate } \\
\text { (SGR), \%/day }\end{array}$ \\
\hline \multicolumn{6}{|l|}{ Year (Y) } \\
\hline Y1 & 360 & $1.04 \pm 0.18 \mathrm{a}$ & $0.97 \pm 0.26 \mathrm{a}$ & $1.67 \pm 0.21 \mathrm{a}$ & $1.35 \pm 0.18 \mathrm{a}$ \\
\hline Y2 & 360 & $0.89 \pm 0.18 b$ & $1.02 \pm 0.26 \mathrm{a}$ & $1.74 \pm 0.21 \mathrm{a}$ & $1.38 \pm 0.18 \mathrm{a}$ \\
\hline \multicolumn{6}{|c|}{ Treatments (T) } \\
\hline T1 & 240 & $0.91 \pm 0.12 \mathrm{a}$ & $0.94 \pm 0.21 \mathrm{~b}$ & $1.63 \pm 0.20 \mathrm{~b}$ & $1.35 \pm 0.16 \mathrm{a}$ \\
\hline T2 & 240 & $0.91 \pm 0.12 \mathrm{a}$ & $0.96 \pm 0.21 \mathrm{~b}$ & $1.73 \pm 0.20 \mathrm{a}$ & $1.38 \pm 0.16 \mathrm{a}$ \\
\hline T3 & 240 & $0.96 \pm 0.12 \mathrm{a}$ & $1.12 \pm 0.21 \mathrm{a}$ & $1.76 \pm 0.20 \mathrm{a}$ & $1.39 \pm 0.16 \mathrm{a}$ \\
\hline \multicolumn{6}{|c|}{ Interaction between $\mathrm{Y} * \mathrm{~T}$} \\
\hline $\mathrm{Y1} 1 * \mathrm{~T} 1$ & 120 & $0.98 \pm 0.11 \mathrm{a}$ & $0.88 \pm 0.14 \mathrm{~b}$ & $1.69 \pm 0.17 \mathrm{a}$ & $1.36 \pm 0.12 b$ \\
\hline $\mathrm{Y} 1 * \mathrm{~T} 2$ & 120 & $1.01 \pm 0.11 \mathrm{a}$ & $0.92 \pm 0.14 \mathrm{ab}$ & $1.66 \pm 0.17 \mathrm{a}$ & $1.35 \pm 0.12 b$ \\
\hline $\mathrm{Y} 1 * \mathrm{~T} 3$ & 120 & $1.07 \pm 0.11 \mathrm{a}$ & $1.06 \pm 0.14 \mathrm{a}$ & $1.70 \pm 0.17 \mathrm{a}$ & $1.36 \pm 0.12 b$ \\
\hline $\mathrm{Y} 2 * \mathrm{~T} 1$ & 120 & $0.88 \pm 0.11 b$ & $1.00 \pm 0.14 \mathrm{ab}$ & $1.60 \pm 0.17 \mathrm{~b}$ & $1.35 \pm 0.12 b$ \\
\hline $\mathrm{Y} 2 * \mathrm{~T} 2$ & 120 & $0.86 \pm 0.11 \mathrm{~b}$ & $0.96 \pm 0.14 \mathrm{ab}$ & $1.80 \pm 0.17 \mathrm{a}$ & $1.42 \pm 0.12 \mathrm{a}$ \\
\hline $\mathrm{Y} 2 * \mathrm{~T} 3$ & 120 & $0.89 \pm 0.11 \mathrm{~b}$ & $1.02 \pm 0.14 \mathrm{a}$ & $1.81 \pm 0.17 \mathrm{a}$ & $1.43 \pm 0.12 \mathrm{a}$ \\
\hline
\end{tabular}

$\mathrm{a}, \mathrm{b}, \mathrm{c} \pm$ Means with the same letter in each column are not significantly different $(\mathrm{P} \geq 0.05)$.

Regarding the effect of pond treatments on condition factor $(\mathrm{K})$ regardless of treatments, Table (5) showeds that, the initial (K) was $0.91,0.91$ and 0.96 for three treatments T1, T2 and T3, respectively. While at the end of experiment the effect of pond treatments on $(\mathrm{K})$ for treatments were $0.94,0.96$ and 1.12 for the three treatments T1, T2 and T3, respectively. These results indicate that, the average of $(\mathrm{K})$ for treatment (T3) was higher $(\mathrm{P}<0.05)$ than other treatments. The analysis of variance of these results indicates that, the differences among treatments were significant $(\mathrm{P}<0.05)$.

Results presented in Table (5) show that variations in $\mathrm{K}$ values were significant $(\mathrm{P}<0.05)$ due to the interaction between years $(2012$ and 2013) and treatments T1, T2 and T3. The averages of initial $(\mathrm{K})$ were $0.98,1.01,1.07,0.88,0.86$ and 0.89 , while, the averages of final $(\mathrm{K})$ were $0.88,0.92,1.06,1.00,0.96$ and 1.02 , respectively for treatments $\mathrm{Y} 1 * \mathrm{~T} 1, \mathrm{Y} 1 * \mathrm{~T} 2, \mathrm{Y} 1 * \mathrm{~T} 3, \mathrm{Y} 2 * \mathrm{~T} 1, \mathrm{Y} 2 * \mathrm{~T} 2$ and $\mathrm{Y} 1 * \mathrm{~T} 3$. As shown in this table, the best final $\mathrm{K}$ value was obtained for the third treatment (Y1*T3, being 1.26) in the first year. Garg et al. (2007) when studied the effect of alternative culture on growth of crops and fish and farmer income, they found that, the alternative culture increased soil nitrogen, improved condition factor and the fish grow well when the supply of food was adequate.

\section{Daily weight gain (DWG):}

Table (5) shows means of daily weight gain (DWG), during the experimental period as affected by years $\mathrm{Y} 1$ and $\mathrm{Y} 2$. As described in this table, the averages of (DWG) of $O$. niloticus were 1.67 and $1.74 \mathrm{~g}$ /fish for year Y1 and Y2, respectively. These results indicate that, the (DWG) for the first year was higher than that obtained in the second year.

Regarding the effect of pond treatments on DWG, table (5) also shows that, the DWG was $1.63,1.73$ and $1.76 \mathrm{~g}$ /fish for the three treatments $\mathrm{T} 1, \mathrm{~T} 2$ and $\mathrm{T} 3$, respectively. These results indicated that, the average DWG for treatment (WO) was higher than the other treatments. Analysis of variance of these results indicates that, the differences among treatments were significant $(\mathrm{P}<0.05)$.

Moreover, the differences in daily weight gain were significant $(\mathrm{P}<0.05)$ due to the interaction between years $\mathrm{Y} 1$ and $\mathrm{Y} 2$ and treatments $\mathrm{T} 1, \mathrm{~T} 2$ and $\mathrm{T} 3$ which indicated that these two factors act dependently and due to changes in water quality and water conditions on each other and also each of them had its own significant 
effect. The averages of (DWG) of $O$. niloticus during the whole period were 1.69, $1.66,1.70,1.60,1.80$ and $1.81 \mathrm{~g} /$ fish for treatments $\mathrm{Y} 1{ }^{*} \mathrm{~T} 1, \mathrm{Y} 1{ }^{*} \mathrm{~T} 2, \mathrm{Y} 1{ }^{*} \mathrm{~T} 3, \mathrm{Y} 2 * \mathrm{~T} 1$, $\mathrm{Y} 2 * \mathrm{~T} 2$ and $\mathrm{Y} 1 * \mathrm{~T} 3$, respectively. As showed in this Table (5), the best (DWG) was obtained for the third treatment (Y2*T3, being 1.81) at the second year. Bwanika (2007) reported that, the of average daily gain of alternative culture was better than the unitary ponds. similar results by Igbinnosa and Okporie (2013) found that, weight gain improved by increasing of nitrogen in earthen ponds due to Integrated Farming System.

\section{Specific growth rate (SGR):}

Table (5) shows means of specific growth rate (SGR), during the experimental period as affected by years Y1 and Y2. As described in this table, the averages of (SGR) of $O$. niloticus were 1.35 and $1.38 \%$ /day, respectively. These results indicate that, the (SGR) for Y1 was higher than obtained in Y2.

Regarding the effect of pond treatments on Specific growth rate (SGR) during the exprimental period, Table 5 shows that, the (SGR) was $1.33,1.38$ and $1.39 \%$ /day for the three treatments $\mathrm{T} 1, \mathrm{~T} 2$ and $\mathrm{T} 3$, respectively. These results indicate that, the average specific growth rate for treatment (Y2*T3, being 1.43\% /day) was higher than other treatments. The analysis of variance of these results indicates that, the differences among treatments were non significant $(\mathrm{P}<0.05)$.

Results presented in Table (5) show that variations were significant $(\mathrm{P}<0.05)$ due to the interaction between years Y1 and Y2 and treatments T1, T2 and T3 which indicated that these two factors act dependently on each other and also each of them had its own significant effect. The averages of (SGR) of Oreochromis niloticus during the whole period were $1.36,1.35,1.36,1.351 .42$ and $1.43 \%$ /day for treatments $\mathrm{Y} 1 * \mathrm{~T} 1, \mathrm{Y} 1 * \mathrm{~T} 2, \mathrm{Y} 1 * \mathrm{~T} 3, \mathrm{Y} 2 * \mathrm{~T} 1, \mathrm{Y} 2 * \mathrm{~T} 2$ and $\mathrm{Y} 1 * \mathrm{~T} 3$, respectively. As shown in Table (5), the best specific growth rate (SGR) was obtained in the third treatment (Y2*T3, being 1.43) in the second year. Rafael (2010) when studied the physiological condition of the halophyte Salicornia bigelovii: Aptential food and biofuel crop for integrated aquaculture agriculture systems, he found that, each species has a specific and unique needs of food and pond fertilization success is critical to a successful education institution aquaculture, were fertilization increases the phytoplankton, zooplankton and other aquatic organisms that fish get them easily, which increased the growth rate.

\section{Total yield:}

Averages of total yield at the end of the experiment are listed in Table (6). As described in this Table O. niloticus gained the highest yield $(20965.40 \mathrm{~kg}-100 \%)$ from all ponds for the year 2012 compared with $21936.49 \mathrm{~kg}-95.57 \%$ gained in the year 2013 from all ponds. These results may be attributed to the effect of wheat culture on aquaculture.

As presented in this Table (6), the third treatment (T3) gained the highest yield $(14742.24 \mathrm{~kg}-100.00 \%)$, compared with (T1) $(13.621 .90 \mathrm{~kg}-92.40 \%)$ and $\mathrm{T} 2$ $(14537.75 \mathrm{~kg}-98.61 \%)$, respectively.

Results presented in Table (6) show that variations due to the interaction between years Y1 and Y2 and treatments T1, T2 and T3 which indicated that these two factors act dependently on each other and also each of them had its own significant effect. The total yield of tilapia increased compared with other feed treatments. (Y2*T3) gained the highest yield $(7654.08 \mathrm{~kg}-100.00 \%)$, compared with treatments, Y1*T1 $(6953.13 \mathrm{Kg}-9084 \%), \mathrm{Y} 1 * \mathrm{~T} 2(6924.11 \mathrm{~kg}-90.46 \%), \mathrm{Y} 1 * \mathrm{~T} 3$ $(7088.16 \mathrm{~kg}-92.61 \%), \mathrm{T} 2 * \mathrm{~T} 1(6668.77 \mathrm{~kg}-87.13 \%)$ and $\mathrm{Y} 2 \mathrm{~T} 2(7613.64 \mathrm{~kg}-$ $99.47 \%)$. 
Table 6: Total yield of two years as affected by alternative culture with wheat crop.

\begin{tabular}{|c|c|c|c|}
\hline Variable & No. & Yield (Kg) & \% of the biggest value \\
\hline Year (Y) & & & \\
\hline Y1 & 360 & 20965.40 & $95.57 \%$ \\
\hline Y2 & 360 & 21936.49 & $100.00 \%$ \\
\hline Treatments (T) & & & \\
\hline T1 & 240 & 13621.90 & $92.40 \%$ \\
\hline T2 & 240 & 14537.75 & $98.61 \%$ \\
\hline T3 & 240 & 14742.24 & $100.00 \%$ \\
\hline Interaction between Y*T & & & \\
\hline Y1*T1 & 120 & 6953.13 & $90.84 \%$ \\
\hline Y1*T2 & 120 & 6924.11 & $90.46 \%$ \\
\hline Y1*T3 & 120 & 7088.16 & $92.61 \%$ \\
\hline Y2*T1 & 120 & 6668.77 & $87.13 \%$ \\
\hline Y2*T2 & 120 & 7613.64 & $99.47 \%$ \\
\hline Y2*T3 & 120 & 7654.08 & $100.00 \%$ \\
\hline
\end{tabular}

This result may return to the fertilization of wheat crop by either organic or nonorganic fertilizers, which led to the increase of nitrogen in the fish docks, becoming a source of natural food. This result somewhat agreed with Rafael (2010) who found that, fertilization increases the phytoplankton, zooplankton and other aquatic organisms that fish get them easily, increasing the growth and total yield.

\section{Economic evaluation:}

Results of costs including variable, fixed costs and interest on working capital for the treatments applied are shown in Table (7). Results of this table revealed that costs of fingerlings of Nile tilapia are similar in all treatments applied, however the feed costs differed according to wheat culture, cattle manure, Triple supper phosphate and ammonium nitrate additive with some diets and were the lowest for Y1T2, compared with other treatments.

Total costs per feddan increased for Y1T2 (35877.46LE- 100\%) and increased to $(35968.95-100.25 \%),(36598.05-102.01 \%),(45768.15-127.57 \%),(49745.15-$ $138.65 \%)$ and (49930.15LE - 139.17\%) for other treatments Y1T1, Y1T3, Y2 T1, Y2 $\mathrm{T} 2$ and Y2T3, respectively. Differences in total costs were attributed to the differences in feed costs, organic and inorganic fertilizer additives and wheat culture coasts.

Total returns in LE/feddan for Y1T1, Y1T2, Y1T3, Y2 T1, Y2 T2 and Y2T3 were 45543.00, 45352.92, 46427.45, 56177.97, 67331.29 and 67181.51LE, respectively (Table 7). Net returns/pond in LE were found to be. 9574.05, 9475.46, 9829.39, 10409.83, 17586.14 and 17251.36LE for treatments Y1T1, Y1T2, Y1T3, Y2 $\mathrm{T} 1, \mathrm{Y} 2 \mathrm{~T} 2$ and Y2T3, respectively. The percentage of net return to total costs were $26.62 \%, 26.41 \%, 26.86 \%, 22.74 \%, 35.35 \%$ and $34.55 \%$ for treatments Y1T1, Y1T2, Y1T3, Y2 T1, Y2 T2 and Y2T3, respectively. 
Table 7: The effect of the experimental factors on economic efficiency (LE/Feddan).

\begin{tabular}{|c|c|c|c|c|c|c|c|}
\hline \multirow{2}{*}{\multicolumn{2}{|c|}{ Items }} & \multicolumn{3}{|c|}{2012} & \multicolumn{3}{|c|}{2012} \\
\hline & & T1 & T2 & T3 & T1 & T2 & T3 \\
\hline \multicolumn{8}{|c|}{ A-Variable costs (LE/Feddan) } \\
\hline \multicolumn{8}{|c|}{ 1-fish production } \\
\hline \multicolumn{2}{|l|}{ a. $O$. niloticus fingerlings } & 2460 & 2460 & 2460 & 2580 & 2580 & 2580 \\
\hline \multicolumn{2}{|l|}{ b. Feeds } & 30468.05 & 30382.01 & 31059.71 & 33358.39 & 36816.65 & 36977.52 \\
\hline \multicolumn{8}{|l|}{ 2- Wheat production } \\
\hline \multicolumn{2}{|l|}{ a. Wheat Seed } & 0 & 0 & 0 & 320 & 320 & 320 \\
\hline \multicolumn{2}{|l|}{ b. Plowing \& Irrigation } & 0 & 0 & 0 & 475 & 475 & 475 \\
\hline \multicolumn{2}{|l|}{ c. Cattle manure } & & 0 & & 720 & 720 & 720 \\
\hline \multicolumn{2}{|c|}{ d. Triple supper phosphate } & 0 & 0 & 0 & 120 & 120 & 120 \\
\hline \multicolumn{2}{|l|}{ e. Ammonium nitrate } & 0 & 0 & 0 & 150 & 150 & 150 \\
\hline \multicolumn{2}{|l|}{ g. harvesting } & 0 & 0 & 0 & 275 & 275 & 275 \\
\hline \multicolumn{2}{|l|}{ h. baler } & 0 & 0 & & 900 & 900 & 900 \\
\hline \multicolumn{2}{|c|}{ Total variable costs (LE/Feddan) } & 32928.05 & 32842.01 & 33519.71 & 38898.39 & 42356.65 & 42517.52 \\
\hline \multicolumn{8}{|l|}{ B- Fixed costs (LE/Feddan) } \\
\hline \multicolumn{2}{|c|}{ a. Depreciation (materials\&others) $10 \%$} & 500 & 500 & 500 & 500 & 500 & 500 \\
\hline \multicolumn{2}{|l|}{ b. Taxes } & 400 & 400 & 400 & 400 & 400 & 400 \\
\hline \multicolumn{2}{|c|}{ Total fixed costs (LE/Feddan) } & 900 & 900 & 900 & 900 & 900 & 900 \\
\hline \multicolumn{2}{|c|}{ Total operating costs (variable\&fixed) } & 33828.05 & 33742.01 & 34419.71 & 39798.39 & 43256.65 & 43417.52 \\
\hline \multicolumn{2}{|c|}{ Interest on working capital * } & 2140.90 & 2135.45 & 2178.34 & 5969.76 & 6488.50 & 6512.63 \\
\hline \multicolumn{2}{|l|}{ Total costs } & 35968.95 & 35877.46 & 36598.05 & 45768.15 & 49745.15 & 49930.15 \\
\hline \multicolumn{2}{|l|}{$\%$ of the smallest value } & $100.25 \%$ & $100 \%$ & $102.01 \%$ & $127.57 \%$ & $138.65 \%$ & $139.17 \%$ \\
\hline \multicolumn{8}{|l|}{ Returns } \\
\hline \multirow{4}{*}{ Total return $(\mathrm{LE}) * *$} & \multirow{3}{*}{$\begin{array}{l}\text { O. niloticus } \\
\text { Wheat } \\
\text { Straw }\end{array}$} & 45543.00 & 45352.92 & 46427.45 & 48348.58 & 55198.89 & 55492.08 \\
\hline & & 0 & 0 & 0 & 7057.99 & 11340.28 & 10904.59 \\
\hline & & 0 & 0 & 0 & 771.4 & 792.12 & 784.84 \\
\hline & Total & 45543.00 & 45352.92 & 46427.45 & 56177.97 & 67331.29 & 67181.51 \\
\hline \multicolumn{2}{|l|}{ Net return (LE/Feddan) } & 9574.05 & 9475.46 & 9829.39 & 10409.83 & 17586.14 & 17251.36 \\
\hline \multicolumn{2}{|c|}{$\%$ of the smallest value of net return } & $101.04 \%$ & $100.00 \%$ & $103.74 \%$ & $109.86 \%$ & $185.60 \%$ & $182.06 \%$ \\
\hline$\%$ Net returns to total co & & $26.62 \%$ & $26.41 \%$ & $26.86 \%$ & $22.74 \%$ & $35.35 \%$ & $34.55 \%$ \\
\hline $\begin{array}{l}* 15 \% \times \text { total operating cos } \\
* * \text { The economical evaluati } \\
\text { O. niloticus }=\text { LE } 205 / 1000 \\
\text { Ammonium nitrate }=\text { LE } 150 \\
\text { Cattle manure }=\text { LE } 45 / \mathrm{m} 3 \\
\text { Fish feed }(25 \% \text { protein })=\end{array}$ & $\begin{array}{l}\text { < 140/365 days. } \\
\text { of results was } \\
\text { y (2012), LE } 21 \\
000 \mathrm{Kg}(2013) \\
13) \\
3200 / 1000 \mathrm{~K}\end{array}$ & $\begin{array}{l}(2012) * 15 \\
\text { rried out ac } \\
/ 1000 \text { fry }( \\
\text { Triple supp } \\
\text { (2012), LE }\end{array}$ & $\begin{array}{l}\times \text { total oper } \\
\text { rding to mar } \\
\text { 13). Wh } \\
\text { phosphate } \\
50 / 1000 \mathrm{~K}\end{array}$ & $\begin{array}{l}\text { ng costs } \times 3 \\
t \text { prices in } 2 \\
\text { t seed }=425 \\
\text { LE } 1200 / 10 \\
2013)\end{array}$ & $\begin{array}{l}5 / 365 \text { days }( \\
12 \text { and } 2013 \\
1000 \mathrm{Kg} \\
\mathrm{Kg}(2013) \text {, }\end{array}$ & $\begin{array}{l}\text { 13) } \\
\text { LE. }\end{array}$ & \\
\hline
\end{tabular}

\section{CONCLUSION}

Based on the results obtained from this study and on the economical evaluation, it could be concluded that, wheat cultivation in ponds during the winter period taking into account organic and inorganic fertilization for wheat crop, feeding Oreochromis niloticus on artificial feed containing $25 \%$ crude protein increased fish weights, as well as wheat yield production in fish ponds, that was good in terms of economic efficiency compared to other treatments.

\section{ACKNOWLEDGMENT}

The authors would like to express pure thanks to Dr. Walid Fares, assistant professor of crop breeding, Central Laboratory of the Research Design and Statistical Analysis, Agricultural Research Center for supervision on the wheat production. 


\section{REFERENCES}

Avila, C.; Salas, J. J.; Martín, I.; Aragón, C. and García, J. (2012). Integrated treatment of combined sewer wastewater and stormwater in a hybrid constructed wetland system in southern Spain and its further reuse. Ecol. Eng., 50: 13-20.

Avnimelech, Y.; Kochva, M. and Diab, S. (1994): Development of controlled intensive aquaculture systems with a limited water exchange and adjusted carbon to nitrogen ratio. Bamidgeh, 46:119-131.

Ayas, S. C.; Aktas, Ô.; Findik, N.; Akca, L. and Kinaci, C. (2013). Effect of recirculation on nitrogen removal in a hybrid constructed wetland system. Ecol. Eng., 40: 1-5.

Baotong, H., (1983). Integrated Fish Farming and the Comprehensive Management of Fisheries, Animal Husbandry and Agriculture.

Baotong, H. (1984). Characteristics of Integrated Fish Farming in China. Sixth Session of the IPFC working Party, 19-25 Jan 1984, New Delhi.

Boyd, C. E. (1979). Water Quality in Warm Water Fish Ponds. Ed Claude E. Boyd. Third printing, 1984. Pub. Auburn Univ., Agri.Exp. Station, AID/Dsan- G.G.00 $39.359 \mathrm{pp}$.

Boyed, C. E. (1998). Water quality for pond aquaculture. Research and development series No. 43. pp. 37. International Centre for aquaculture and aquatic Environments. Alabama Agricultural Experiment Station. Auburn University.

Britton, C. J. (1963). "Disorders of the Blood", $9^{\text {th }}$ ed. I. A. Churchill, Ld. London. United Kingdom.

Bwanika, G. N.; Murie, D. J. and Chapman, L. J. (2007). Comparative age and growth of Nile tilapia (Oreochromis niloticus L.) in earth pond Nabugabo and Wamala, Uganda. Hydrobiol., 589: 287-301.

Chan, G. L., (2006). Integrated farming system. What Does Integrated Farming System Do.

Diana, J. S., and Lin, C. K. (1998). The effects of fertilization and water management on growth and production of Nile tilapia in deep ponds during the dry season. J. of the World Aquaculture Society, 29 (4): 405 - 413.

Decie, S. and Lewis, S. (1984). Practical hematology 7th ed., Churchill Livingstone, London.

Dumas, B. T. and Biggs, H. G. (1972). Standard Methods of Clinical Chemistry. Ed., Academic Press, New York.

Duncan, D. B. (1955). Multiple range and multiple F test. Biometrics, 11:1-42.

Ebe, F. E. (2012). Economic study of fuel wood marketing and consumption in Enugu state, Nigeria. Ph.D. Thesis, University of Nigeria, Nsukka.

Franzen, D. W.; McMullen, M. and Mossett, D. S. (2008). Spring wheat and durum yield and disease responses to copper fertilization of mineral soils. Agronomy Journal 100: 371-375.

Garg, S. K.; Garg, R. and Garg, R. (2007). Environmental Science and Ecological Studies. Khanna Publishers, Nai Sarak, Delhi.

Gikas, G. D. and Tsihrintzis, V. A. (2012). A small-size vertical flow constructed wetland for on-site treatment of household wastewater. Ecol. Eng., 44: 337-343.

Henry, R. J. (1964). Colorimetric determination of total protein. In: Clinical Chemistry. Harper and Row Publ., New York, 181 pp. 
Igbinnosa, I. and Okporie, I. (2013). Preparation of training toolkit for sustainable farming system. Consultant Draft Report-Second National FADAMA Development-Critical Ecosystem Management Project.

Jauncey, K. and Rose, B. (1982). A guide to tilapia feeds and feeding. Institute of Aquaculture, University of Sterling, Scotland.

Jürg, M. and Donald, H. (2013). Fertilizing Winter Wheat II Phosphorus. University of Nebraska-Lincoln Extension educational programs abide with the nondiscrimination policies of the University of Nebraska-Lincoln and the United States Depart. of Agricult.

Jian, X.; Liangliang, H.; Jianjun, T.; Xue, W.; Nana, L.; Yongge, Y.; Haishui, Y.; Jiaen, Z.; Shiming, L., and Xin, C. (2011) Ecological mechanisms underlying the sustainability of the agricultural heritage crops-fish coculture system PNAS, December 13, 2011. vol. 108. no. 50: 1381-1387pp.

Johanna, J. H.; Steven, M.; Ussif, R. S; Andrew, D. and Alyson, L. (2011). The Impact of Subsidies on the Ecological Sustainability and Future Profits from Fisheries. May 2011 | Volume 6 | Issue 5 | e20239: 1-13 pp.

Kamal, S. M; Abdel Ghanny, S. and Abdel All, M. M. (2008): Effect of nutrition and fertilization on production of Nile Tilapia (O. Niloticus) fingerlings in concrete ponds. Proceedings of the 8th international symposium on Tilapia in aquaculture, Volume (1), pp: 387-401. Cairo International Convention Center (CICC), Egypt, 12-14 October, 2008.

Othman, K., (2006). Integrated farming system and multifunctionality of agriculture in Malaysia. Acta Hortic., 655: 291-296.

Rafael, M. G. (2010). Physiological studies of the halophyte (Salicornia bigelovii) Aptential food and biofuel crop for integrated aquaculture agriculture systems. $\mathrm{Ph} . \mathrm{D}$. Thesis, College of graduate, Arizona University.

Reitman, S. and Frankel, S. (1957). A colorimetric method for the determination of serum glutamic oxaloaceitic and glutamic pyruvic transaminases. American Journal of Clinical Pathology, 28: 56-63.

Salah, M. M. I. (2003). Field studies in semi-intensive production system of Nile tilapia fish. Msc. Thesis, Fac. Agric., Mansoura Univ.

SAS (1996). SAS procedure Guide "Version 6.12 ed". SAS Institute Inc., Cray, NC, USA.

Shalaby, A. M.; Khattab,Y. A. and Azza, M. Abdel Rahman (2006). Effects of garlic (Allium sativum) and chloramphenicol on growth performance, physiological parameters and survival of Nile tilapia (Oreochromis niloticus). J. Venom. Anim. Toxins incl. Trop. Dis.V.12, 2: 172-201 pp.

Sophin, P. (2007). Waste recycling and fish culture, literature review. Sophin - uta @ forum. Arg. Kh.

Stephen J. Brady, (2007). Effects of Cropland Conservation Practices on Fish and Wildlife Habitat. The Wildlife Society Technical Review, 07-12.

Thy, S., (2006). Management and utilization of bio-digesters in integrated farming systems. Biodigesters in Integrated Farming.

Tokrishna, R., (2006). Integrated livestock-fish farming systems in Thailand.

Ugwumba, C. O. A. and Orji, E. C. (2006). Traditional farming system and it effect on farm cash income in old njikoka local government area of Anambra state. Int. J. Agric. Res. Politics, 1: 21-24.

Vankampen, E. J. (1961). Determination of haemoglobin. Clin. Chem. Acta, 5: 719720 . 
White, J. R. and Reddy, K. R. (2003). Potential nitrification and denitrification rates in a phosphorus-impacted subtropical peatland. J. Environ. Qual., 32: 24362443.

\section{ARABIC SUMMARY}

تأثير العمليات الزراعية لإتتاج محصول القمح من أحواض الأسماك على أداء النمو والمحصول الكلى لأسماك البلطي النيلي.

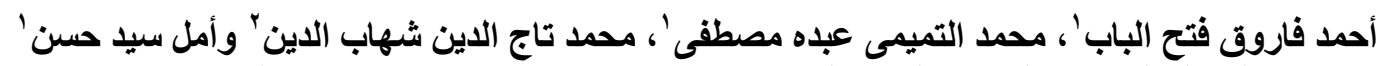

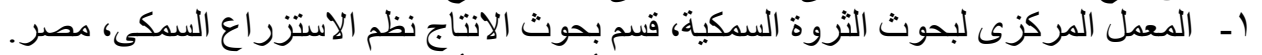

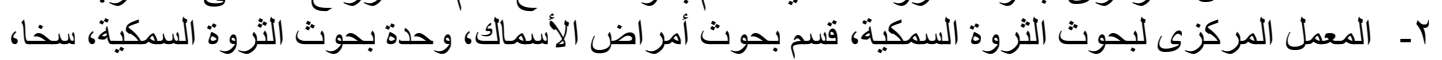
كفر الثيخ، مصر.

هدفت هذه الدراسة إلى تأثير العمليات الزر اعية لإنتاج محصول القمح من أحو اض السمك على فئى

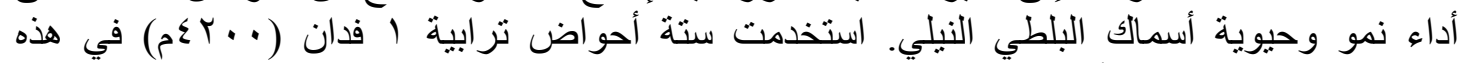

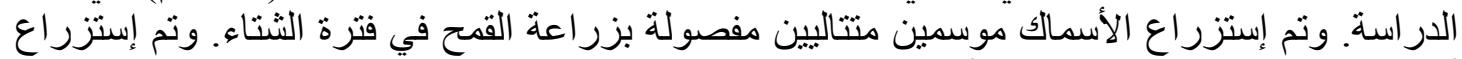

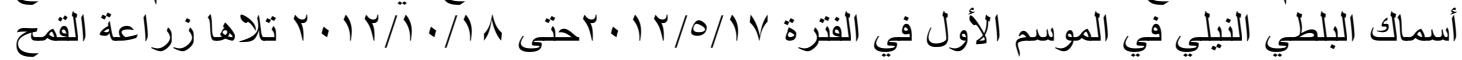

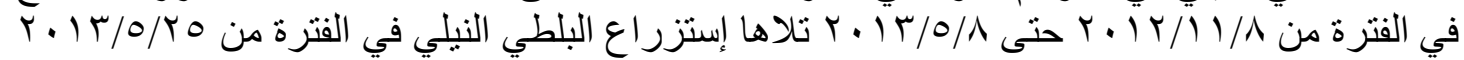

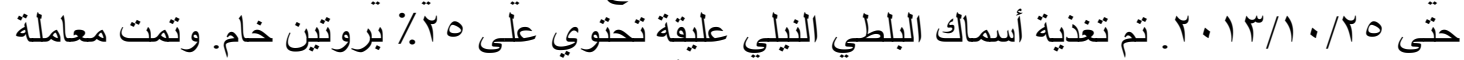

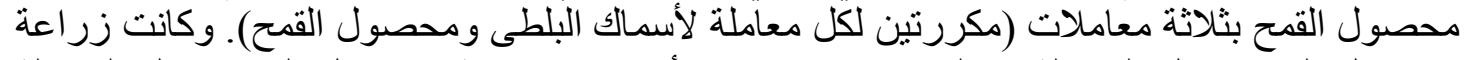

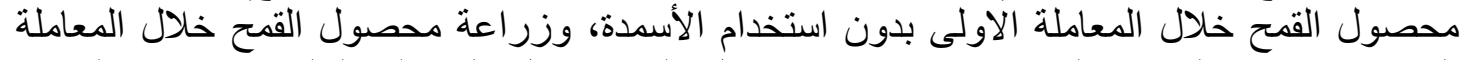

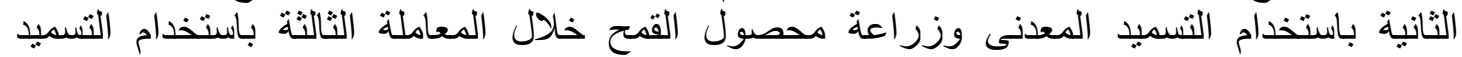

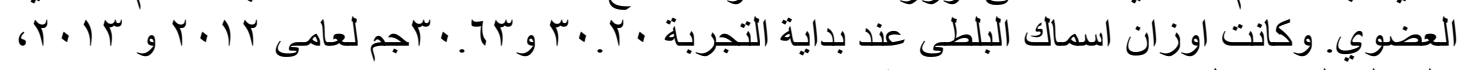

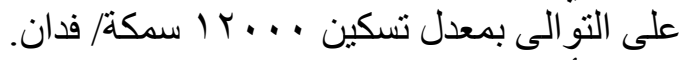

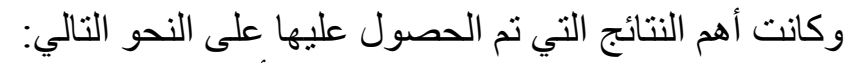

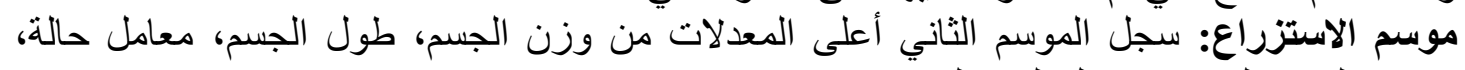

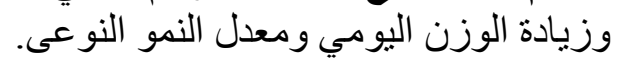

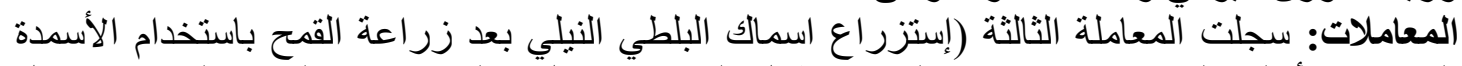

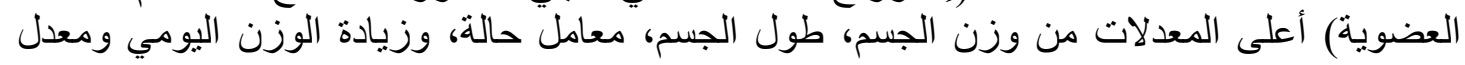

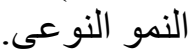
زراعة محصول القمح: سجلت المعاملة الثانية (زراعة القمح بالتسميد المعدنى) أعلى معدلات لصفات

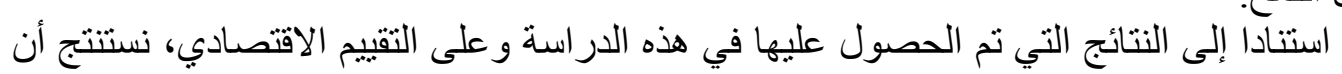
محصول القمح.

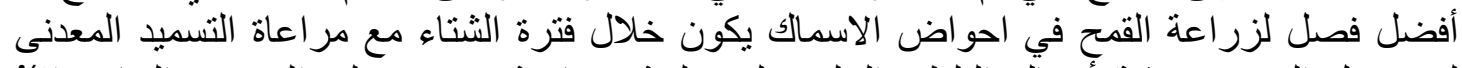

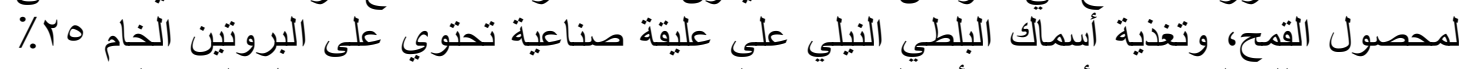

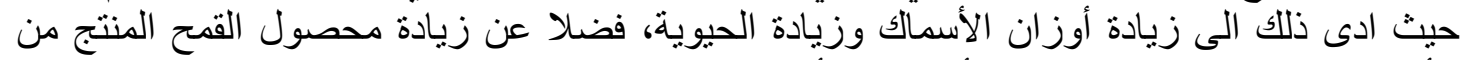

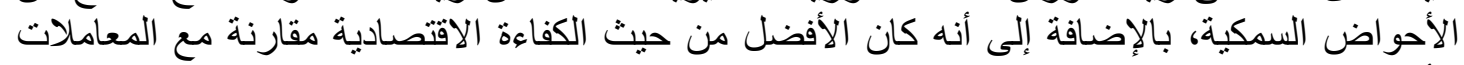

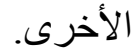

